\title{
DETERMINATION OF SERUM ADENOSINE DEAMINASE AND XANTHINE OXIDASE LEVELS IN PATIENTS WITH CRIMEAN-CONGO HEMORRHAGIC FEVER
}

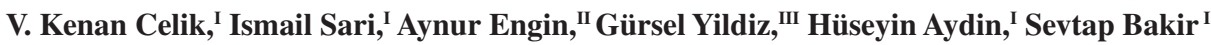 \\ doi: $10.1590 / \mathbf{S 1 8 0 7 - 5 9 3 2 2 0 1 0 0 0 0 7 0 0 0 0 8}$
}

Celik VK, Sari I, Engin A, Yildiz G, Aydin H, Bakir S.Determination of serum adenosine deaminase and xanthine oxidase levels in patients with crimean-congo hemorrhagic fever. Clinics. 2010; 65(7):697-702.

OBJECTIVE: Crimean-Congo hemorrhagic fever is an acute viral hemorrhagic fever with a high mortality rate. Despite increasing knowledge about hemorrhagic fever viruses, little is known about the pathogenesis of Crimean-Congo hemorrhagic fever. In this study, we measured serum adenosine deaminase and xanthine oxidase levels in Crimean-Congo hemorrhagic fever patients.

METHODS: Serum adenosine deaminase levels were measured with a sensitive colorimetric method described by Giusti and xanthine oxidase levels by the method of Worthington in 30 consecutive hospitalized patients (mean age 42.6 \pm 21.0 ). Laboratory tests confirmed their diagnoses of Crimean-Congo hemorrhagic fever. Thirty-five subjects (mean age 42.9 \pm 19.1 ) served as the control group.

RESULTS: There was a significant difference in adenosine deaminase and xanthine oxidase levels between cases and controls $(\mathrm{p}<0.05)$. However, neither adenosine deaminase nor xanthine oxidase levels varied with the severity of disease in the cases assessed $(\mathrm{p}>0.05)$.

CONCLUSION: Adenosine deaminase and xanthine oxidase levels were increased in patients with Crimean-Congo hemorrhagic fever. Elevated serum xanthine oxidase activity in patients with Crimean-Congo hemorrhagic fever may be associated with reactive oxygen species generated by the xanthine/xanthine oxidase system during inflammatory responses. In addition, elevated lipid peroxidation may contribute to cell damage and hemorrhage. The association of cell damage and hemorrhage with xanthine oxidase activity should be further investigated in large-scale studies.

KEYWORDS: Crimean-Congo hemorrhagic fever; Adenosine deaminase; Xanthine oxidase; intracellular enzyme; Nairovirus.

\section{INTRODUCTION}

Crimean-Congo hemorrhagic fever (CCHF) is an acute viral disease with a high mortality $(3-30 \%)$ rate. ${ }^{1,2}$ It is caused by the CCHF virus (CCHFV). The virus belongs to the genus Nairovirus in the Bunyaviridae family. CCHF was first described in the 1940s, when more than 200 human

\footnotetext{
${ }^{\text {I }}$ Department of Biochemistry, Cumhuriyet University, School of Medicine - Sivas, Turkey.

"Department of Infectious Diseases and Clinical Microbiology, Cumhuriyet University, School of Medicine - Sivas, Turkey.

III Department of Nephrology, Cumhuriyet University, School of Medicine - Sivas, Turkey.

Email: vkcelik@cumhuriyet.edu.tr

Tel: 903462581492

Received for publication on March 20, 2010

First review completed on April 19, 2010

Accepted for publication on April 28, 2010
}

cases occurred in the Crimean peninsula of the former Soviet Union, and it is now described in about 30 countries in Africa, Asia, Europe and the Middle East. ${ }^{3}$

CCHF, seen in approximately 30 countries worldwide, is a tick-borne disease with increasing importance and prevalence worldwide. ${ }^{4-11}$ Humans are infected through tick bites (especially Hyalomma species), by crushing infected ticks, or by contact with blood or tissue from acute-phase CCHF patients or viremic livestock. Most human cases occur in workers in the livestock and agriculture industries, slaughterhouses, and veterinary practices. ${ }^{12}$ Most patients (90\%) with CCHF in Turkey have been farmers who were infected during outbreaks. ${ }^{2,4,5}$

There is a history of tick bite in approximately half (50-60\%) of CCHF patients. ${ }^{2,4,5}$ The incidence of the disease is $20 \%$ among those who are infected. ${ }^{13}$ The course of CCHF infection has four distinct periods: incubation, 
prehemorrhagic, hemorrhagic, and convalescence. ${ }^{3}$ The incubation period for CCHF ranges from 2 to 12 days after the tick bite. This period ranges from 3 to 10 days in nosocomial cases. ${ }^{14,15}$ The prehemorrhagic period ranges from 1 to 7 days. The typical clinical symptoms during this period are sudden onset of fever $\left(39-41^{\circ} \mathrm{C}\right)$, severe headache, myalgia, and dizziness. ${ }^{2-5,15,16}$ Additional symptoms include diarrhea, nausea and vomiting. ${ }^{1,15,16}$ Cutaneous flushing or rash occur on the face, neck and chest during this period. Bradycardia and fever-pulse discordance are also observed. ${ }^{17}$ The hemorrhagic period develops rapidly and usually begins between the fifth and seventh days of disease. ${ }^{1}$ Patients may show signs of progressive hemorrhagic diathesis, such as petechiae, mucous membranes hemorrhage, conjunctival hemorrhage, nosebleed, hemoptysis, hematuria, hematemesis, and melena. ${ }^{1,17,18}$ Hepatomegaly and splenomegaly have been reported to occur in one-third of patients. ${ }^{3}$ The convalescence period begins in survivors approximately 10-20 days after the onset of illness. Patients usually require hospitalization for about 9-10 days. ${ }^{1,16}$ During the convalescence period, tachycardia, temporary complete hair loss, polyneuritis, difficulty in breathing, xerostomia, poor vision, loss of hearing, and loss of memory have been reported. ${ }^{3}$ Death usually occurs after 6-14 days of the disease.

It has been reported that mononuclear phagocytes, hepatocytes, and endothelial cells are major targets of CCHF virus infection. ${ }^{19}$ Despite increasing knowledge about hemorrhagic fever viruses, little is known about the pathogenesis of $\mathrm{CCHF}^{29}$

Adenosine deaminase (ADA; EC 3.5.4.4) is an enzyme that transforms, respectively, adenosine and deoxyadenosine to inosine and deoxyinosine, a stage of purine metabolism. In the ensuing reaction hypoxanthine is formed. The oxidation of hypoxanthine to xanthine and the oxidation of xanthine to uric acid are catalyzed by xanthine oxidase (XO; EC 1.1.3.22). ADA has two principal isoenzymes, ADA-1 and ADA-2. The low-molecular-weight ADA-1 is found in many tissues but predominantly in lymphocytes. The high-molecularweight ADA-2 is predominantly found in monocytes and macrophages. ${ }^{21,22}$ ADA-1 and ADA-2 play an important role in the function of immune cells. Increased serum/ plasma ADA activity, comprising both ADA-1 and ADA-2 activity, has been used as a biochemical marker for infectious diseases. ${ }^{22-24}$ Increased serum ADA has been reported in infectious diseases such as viral and bacterial pneumonia, HIV infection, extra-pulmonary and pulmonary tuberculosis, visceral leishmaniasis, and mononucleosis. ${ }^{21,22,25}$

Xanthine oxidase is another intracellular enzyme that plays a role in nucleotide metabolism. It is involved in the catabolism of hypoxanthine and xanthine, which are formed during adenosine catabolism. The reactive oxygen species formed as a result of this reaction induce tissue damage in some viral diseases such as influenza. ${ }^{26}$

The aim of the present study was to investigate the serum levels of ADA-2 (the main source of ADA activity in the serum, which plays crucial roles in immune function) and xanthine oxidase (which increases tissue damage via the formation of free oxygen radicals) in CCHF patients and to compare the results with those obtained for healthy controls. We also determined whether the activities of these two intracellular enzymes were related to the severity of disease.

\section{MATERIALS AND METHODS}

\section{Study population}

This prospective study was conducted between April 1 and July 31, 2008 in Cumhuriyet University Hospital in Sivas, a city located in central Anatolia. The study protocol was approved by the Human Ethics Committee of the Cumhuriyet University Faculty of Medicine. Informed consent was obtained from each patient.

Thirty consecutive hospitalized patients, diagnosed with CCHF by laboratory tests, and 35 healthy volunteer adults, as controls who had no infections or immune system diseases such as rheumatoid arthritis, psoriasis and sarcoidosis, were included in this study.

\section{Blood collection}

Venous blood samples were collected in tubes after an 8-h fast and immediately stored at $4^{\circ} \mathrm{C}$. Next, the serum was separated from the cells and fibrines by centrifugation at $1610 \mathrm{xg}$ for $10 \mathrm{~min}$ and stored in several aliquots at $-80^{\circ}$ $\mathrm{C}$ until assayed. A second blood sample from each patient was obtained and sent to the Virology Laboratory of Refik Saydam Hygiene Central Institute, Ankara, Turkey, for serologic and virologic analyses to confirm the diagnosis of CCHF. The definitive diagnosis of CCHF infection was based on typical clinical and epidemiological findings and the detection of CCHF virus-specific IgM by enzyme-linked immunosorbent assay (ELISA) or of genomic segments of the CCHF virus by reverse-transcription polymerase chain reaction (RT-PCR). All CCHF patients were classified into two groups in terms of disease severity (severe, non-severe), according to the predictive factors for fatal outcome criteria reported by Swanepoel and co-workers. ${ }^{15}$

\section{Chemicals}

Adenosine and hypoxanthine were supplied by Sigma- 
Aldrich (Steinheim, Germany). All other chemicals used were obtained from Merck Darmstadt (Germany) and were of analytical grade.

\section{Measurement of enzyme activities}

ADA activity was estimated by the sensitive colorimetric method described by Giusti, and XO activity was determined by the method of Worthington. ${ }^{27,28}$ The assay results are expressed as specific activity (units per milligram of protein).

\section{Statistical analysis}

Parametric data are expressed as the mean \pm standard deviation and categorical data as percentages. The Statistical Package for the Social Sciences (SPSS) version 14 for Windows (SPSS Inc., Chicago, IL, USA) was used for the statistical analysis. Parametric data were evaluated by the independent sample t-test and categorical data by the chisquared test. A p value $\leq 0.05$ was considered as significant.

\section{RESULTS}

Thirty patients with CCHF and 35 control subjects were recruited for the study. Of the CCHF patients, 14 (47\%) were male and $16(53 \%)$ female, and the mean age was $42.6 \pm 21$ years. In the control group, twenty (57\%) individuals were male and $15(43 \%)$ were female, with a mean age of $42.9 \pm 19.1$ years. There were no significant differences in the age or sex ratio between patients with CCHF and controls $(\mathrm{p}>0.05)$.

All of the CCHF patients presented positive IgM and/or RT-PCR results for CCHF virus in the blood samples. Five (17\%) of 30 patients had CCHFV-specific IgM antibodies, 6/30 (20\%) had a positive RT-PCR test for CCHFV, and $19 / 30(63 \%)$ were positive in both tests during the acute and/or convalescent phase of the disease. According to the severity score, 11 (37\%) CCHF patients were classified as "severe", whereas the remaining 19 (63\%) patients were classified as "non-severe". Only one patient with CCHF died during the hospitalization period. Table 1 shows the demographic, clinical and laboratory data for the patients and controls.

Serum ADA and XO levels in patients with CCHF were significantly higher than were those determined for the control group $(\mathrm{p}<0.05)$, as shown in Table 2 . We found no significant difference in the serum ADA or XO level between severe and non-severe patients. Furthermore, no relationship was detected between $\mathrm{XO}$ and ALT levels in patients with CCHF ( $>00.05)$.
Table 1- Demographic, clinical and laboratory data for patients with Crimean-Congo hemorrhagic fever and the control group.

\begin{tabular}{|c|c|c|c|}
\hline & $\begin{array}{l}\text { CCHF } \\
(\mathrm{n}=30)\end{array}$ & $\begin{array}{l}\text { Control } \\
\text { Group } \\
(\mathrm{n}=35)\end{array}$ & $\begin{array}{c}\mathrm{P} \\
\text { value }\end{array}$ \\
\hline Mean age (year) & $42.6 \pm 21.0$ & $42.9 \pm 19.1$ & NS \\
\hline Sex (female/male) & $16 / 14$ & $15 / 20$ & NS \\
\hline FINDINGS & n $(\%)$ & & \\
\hline $\begin{array}{l}\text { Most common symptoms } \\
\text { Myalgia } \\
\text { Fever }\end{array}$ & $\begin{array}{c}18(60) \\
26(86.7)\end{array}$ & & \\
\hline $\begin{array}{l}\text { Physical finding } \\
\text { Fever }^{\mathrm{a}} \\
\text { Conjunctival hyperemia } \\
\text { Maculopapular rash } \\
\text { Petechia/ecchymosis } \\
\text { Bleeding* }\end{array}$ & $\begin{array}{l}26(86.7) \\
6(20) \\
7(23) \\
6(20) \\
7(23)\end{array}$ & & \\
\hline $\begin{array}{l}\text { Laboratory findings } \\
\text { Thrombocytopenia }^{\mathbf{b}} \\
\text { Leukopenia }^{\mathrm{c}} \\
\text { Elevated AST } \\
\text { Elevated ALT }\end{array}$ & $\begin{array}{l}29(96.7) \\
27(90) \\
21(70) \\
16(53.3)\end{array}$ & & \\
\hline $\begin{array}{l}\text { Risk factors for CCHF } \\
\text { History of tick bite } \\
\text { History of tick removal from animal } \\
\text { No tick exposure }\end{array}$ & $\begin{array}{c}19(63) \\
5(17) \\
6(20)\end{array}$ & & \\
\hline
\end{tabular}

Table 2 - Serum ADA and XO levels in CCHF patients and controls.

\begin{tabular}{lccc}
\hline & $\begin{array}{c}\text { CCHF } \\
(\mathbf{n}=\mathbf{3 0})\end{array}$ & $\begin{array}{c}\text { Control } \\
\text { Group } \\
(\mathbf{n = 3 5})\end{array}$ & p value \\
\hline $\begin{array}{l}\text { ADA specific activity } \\
\text { (U/mg protein) }\end{array}$ & $1.16 \pm 0,47$ & $0.27 \pm 0,06$ & 0.000 \\
$\begin{array}{l}\text { XO specific activity } \\
\text { (U/mg protein) }\end{array}$ & $2.23 \pm 1,18$ & $0.23 \pm 0,19$ & 0.000 \\
\hline
\end{tabular}

Data are expressed as the mean \pm standard deviation. CCHF, Crimean-Congo hemorrhagic fever; ADA, adenosine deaminase; XO, xanthine oxidase.

\section{DISCUSSION}

Patients infected with CCHFV were first reported in Turkey in 2002. ${ }^{4}$ Since 2002, CCHF outbreaks have been reported in rural areas of Turkey every year, especially in the spring and summer. To date, nearly 1800 confirmed CCHF cases have been reported in Turkey. ${ }^{29}$ Although the reported mortality rate for $\mathrm{CCHF}$ is $3-30 \%,{ }^{1,2}$ the fatality rate in Turkey is $5 \% .{ }^{29}$ Midilli et al. reported that all strains clustered within the same group with the Europe/Turkey isolates, despite their origins in eight different geographic areas of Turkey. ${ }^{30}$ It is not clear why those similar virus 
strains cause an asymptomatic clinical course in some patients but have a fatal outcome in others.

ADA deficiency is the major metabolic cause of severe combined immunodeficiency disease. ${ }^{31,32} \mathrm{ADA}$ is important for the development of the immune system in humans. It seems to be associated with the differentiation of epithelial cells and monocytes and with neurotransmission. ${ }^{33}$ Monocyte/macrophage activation by intracellular infection and inflammatory diseases leads to the release of ADA and elevated levels in the serum. ${ }^{34}$ Monocyte involvement in CCHF has been well described..$^{19}$ However, no studies have reported the ADA/XO levels in patients with CCHF.

Increased serum ADA has been reported in infectious diseases such as viral and bacterial pneumonia, HIV infection, extra-pulmonary and pulmonary tuberculosis, visceral leishmaniasis, and mononucleosis. ${ }^{21,22,25}$

$\mathrm{XO}$ is another intracellular enzyme that plays a role in nucleotide metabolism. Vorbach and co-workers ${ }^{35}$ suggest that xanthine oxidoreductase (XOR) is central to the development and function of innate immunity. In purine catabolism, XOR catalyzes the oxidative hydroxylation of hypoxanthine to xanthine and subsequently of xanthine to uric acid. In this reaction, reactive oxygen species (ROS) such as superoxide anions $\left(\mathrm{O}^{2-}\right)$, hydroxyl radicals $\left(\mathrm{OH}^{-}\right)$and hydrogen peroxide $\left(\mathrm{H}_{2} \mathrm{O}_{2}\right)$ are produced. ROS may contribute to tissue damage in some viral infections such as influenza. ${ }^{9}$ XOR exists in two forms: xanthine dehydrogenase (XD; EC 1.1.1.204) and xanthine oxidase (XO; EC 1.1.3.22). In the normal physiological state, the XO activity in many tissues is very low, but it has been shown to increase dramatically following viral infection. ${ }^{26}$

There have been numerous recent studies on CCHF. These studies have focused on clinical and laboratory features or genetic characteristics. ${ }^{30,36-38}$ However, there are no reports concerning serum ADA and XO levels in CCHF patients.

In the present study, we investigated serum ADA and serum XO activity in CCHF patients and controls. Serum ADA and XO levels in patients with CCHF were significantly higher than were those determined for the control group $(\mathrm{p}<0.05)$, whereas no significant association was observed between the serum ADA or XO level and the severity of disease in CCHF patients ( $p>0.05$ ).

An increased serum level of ADA has been reported in infectious diseases such as HIV infection, tuberculosis, and visceral leishmaniasis. ${ }^{22,25,39}$ However, the present study is the first to describe increased serum ADA and $\mathrm{XO}$ in $\mathrm{CCHF}$ patients.

Chittiprol and co-workers found high levels of plasma ADA in HIV-infected patients compared with controls, and this high level of ADA was associated with lymphocyte and monocyte infection by HIV. A similar mechanism of infection may occur in CCHF patients because monocytes can be infected by CCHFV. ${ }^{22}$

Whereas XO causes tissue damage by producing ROS, it can also protect against some infections by causing the production of uric acid and superoxide radicals. ${ }^{33,35}$ ROS generated by xanthine oxidase, such as superoxide anion radicals $\left(\mathrm{O}^{2-}\right)$ and hydrogen peroxide $\left(\mathrm{H}_{2} \mathrm{O}_{2}\right)$, may contribute to the tissue damage. The overproduction of these highly reactive oxygen metabolites can initiate lethal radical chain reactions involving the oxidation and damage of structures that are crucial for cellular integrity and survival.

XOR is highly expressed in the liver for purine catabolism. Stirpe and co-workers reported that the level of total XOR was significantly higher in liver with virus-related cirrhosis but not in virus-negative cirrhosis, as compared to the controls. ${ }^{35,40,41}$ The level of XOR was increased in cirrhotic liver, in association with viral infection. This increase correlated with ALT, suggesting a relationship between XOR activity and the extent of liver injury caused by viral replication. The extent of oxidase activity seems to be correlated with tissue damage and consequent liver impairment. However, in our study, the XO level was highest in the patient group, and no relationship was observed between XO and ALT levels.

Tumor necrosis factor (TNF)- $\alpha$ and IL-6 are increased in CCHF infection. ${ }^{42,43}$ The inflammatory reaction results in the expression of various cytokines, and XOR is stimulated by interferon (IFN)- $\gamma$, IFN- $\alpha$, TNF- $\alpha$, interleukin (IL)- 1 and IL3 ; some of these factors also initiate the conversion from the $\mathrm{XD}$ to the XO form. ${ }^{35}$ Increased TNF- $\alpha$ or liver cell damage in CCHF patients may contribute to the increased XO level. However, this study was not designed to investigate the cause of the elevated ADA and XO levels in CCHF patients. Therefore, larger-scale studies are needed to explain this phenomenon.

We hypothesize that the elevated serum XO activity in patients with $\mathrm{CCHF}$ is related to the free radicals generated by the xanthine/XO system. In addition, elevated lipid peroxidation may contribute to cell damage and hemorrhage. Therefore, serum ADA/XO activity, a relatively simple laboratory test parameter, particularly in the absence or in the event of delays in molecular procedures such as PCR and CCHF IgM detection, could supplement the laboratory approach for CCHF diagnosis and could be used to take preventive measures.

In conclusion, we showed that ADA and XO levels were increased in patients with CCHF. However, we found no significant association between the serum ADA or XO level and the severity of disease in CCHF patients. 


\section{REFERENCES}

1. Watts DM, Ksiasek TG, Linthicum KJ, Hoogstraal H. Crimean-Congo Hemorrhagic fever. In T.P. Monath, ed. The arboviruses: epidemiology and ecology, vol.2. CRC, Boca Raton, FL,USA. 1988;177-260.

2. Ergönül O, Çelikbas A, Dokuzoguz B, Eren S, Baykam N, Esener H. The characteristics of Crimean-Congo Hemorrhagic Fever in a recent outbreak in Turkey and the impact of oral ribavirin therapy. Clin Infect Dis. 2004;39:284-7.

3. Ergönül O. Crimean-Congo haemorrhagic fever. Lancet Infect Dis. 2006;6:203-14.

4. Karti SS, Odabaşı Z, Korten V, Yılmaz M, Sönmez M, Caylan R, et al. Crimean-Congo hemorrhagic fever in Turkey. Emerg Infect Dis. 2004;10:1379-84.

5. Bakır M, Ugurlu M, Dokuzoguz B, Bodur H, Tasyaran MA, Vahaboglu H. Crimean-Congo haemorrhagic fever outbreak in Middle Anatolia: a multicentre study of clinical features and outcome measures. J Med Microbiol. 2005;54:385-9.

6. Smego RA, Sarwari AR, Siddiqui AR. Crimean-Congo hemorrhagic fever: Prevention and control limitations in a resource poor country. Clin Infect Dis. 2004;38:1731-5.

7. Mardani M, Jahromi MK, Naieni KH, Zeinali M.The efficacy of oral ribavirin in the treatment of crimean-congo hemorrhagic fever in Iran. Clin Infect Dis. 2003;36:1613-8.

8. Nabeth P, Thior M, Faye O, Simon F. Human Crimean-Congo hemorrhagic fever, Senegal. Emerg Infect Dis. 2004;10:1881-2.

9. Papa A, Bino S, Llagami A, Brahimaj B, Papadimitriou E, Pavlidou V, et al. Crimean Congo hemorrhagic fever in Albania, 2001. Eur J Clin Microbiol Infect Dis. 2002;21:603-6.

10. Papa A, Bozovic B, Pavlidou V, Papadimitriou E, Pelemis M, Antoniadis A. Genetic detection and isolation of Crimean-Congo hemorrhagic fever virus, Kosovo, Yugoslavia. Emerg Infect Dis. 2002;8:852-4.

11. Papa A, Christova I, Papadimitriou E, Antoniadis A. Crimean-Congo hemorrhagic fever in Bulgaria. Emerg Infect Dis. 2004;10:1465-7.

12. Athar MN, Baqai HZ, Ahmad M, Khalid MA, Bashir N, Ahmad AM, et al. Short report: Crimean-Congo hemorrhagic fever outbreak in Rawalpindi, Pakistan. Am J Trop Med Hyg. 2003;69:284-7.

13. Goldfarb LG, Chumakov MP, Myskin AA, Kondratenko VF, Reznikov OY. An epidemiological model of Crimean Hemorrhagic Fever. Am J Trop Med Hyg. 1980; 29:260-4.

14. Elald 1 N. Epidemiology of Crimean-Congo hemorrhagic fever, Klimik Derg 2004;17:151-5. Turkish.

15. Swanepoel R, Gill DE, Shepherd AJ, Leman PA,Mynhardt JH, Harvey $\mathrm{S}$. The clinical pathology of Crimean/Congo hemorrhagic fever. Rev Infect Dis. 1989;11:794-800.

16. Schwarz TF, Nsanze H, Ameen AM. Clinical features of Crimean-Congo haemorrhagic fever in the United Arab Emirates. Infection. 1997;25:3647.

17. Oldfield EC, Wallace MR, Hyams KC, Yousif AA, Lewis DE, Bourgeois AL. Endemic infectious diseases of the Middle East, Rev Infect Dis. 1991;13:199-217.
18. Celikbas A, Ergonul O, Baykam N, Eren S, Esener H, Dokuzoguz B. Analysis of the mortality among the patients with Crimean Congo Hemorrhagic Fever virus infection. 15th European Congress of Clinical Microbiology and Infectious Diseases, April 2-5, 2005, Copenhagen. Clin Microbiol Infect. 2005;11:19.

19. Burt FJ, Swanepoel R, Shieh WJ, Smith JF, Leman PA, Greer PW, et al. Immunohistochemical and in situ localization of Crimean-Congo hemorrhagic fever (CCHF) virus in human tissues and implications for CCHF pathogenesis. Arch Pathol Lab Med. 1997;121:839-46.

20. Whitehouse CA. Crimean-Congo hemorrhagic fever. Antiviral Res. 2004;64:145-60.

21. Ungerer JP, Oosthuizen HM, Bissbort SH, Vermaak WJ. Serum adenosine deaminase: isoenzymes and diagnostic application. Clin Chem. 1992;38:1322-6.

22. Chittiprol S, Satishchandra P, Bhimasenarao RS, Rangaswamy GR, Sureshbabu SV, Subbakrishna DK, et al. Plasma adenosine deaminase activity among HIV1 Clade C seropositives: relation to CD4 T cell population and antiretroviral therapy. Clin Chim Acta. 2007;377:133-7.

23. Tuon FF, Silva VI, Almeida GM, Antonangelo L, Ho YL. The usefulness of adenosine deaminase in the diagnosis of tuberculous pericarditis. Rev Inst Med Trop. 2007;49: 165-70.

24. Choi SH, Kim YS, Bae IG, Chung JW, Lee MS, Kang JM, et al. The possible role of cerebrospinal fluid adenosine deaminase activity in the diagnosis of tuberculous meningitis in adults. Clin Neurol Neurosurg. 2002;104:10-5.

25. Tripathi K, Kumar R, Bharti K, Kumar P, Shrivastav R, Sundar S, et al. Adenosine deaminase activity in sera of patients with visceral leishmaniasis in India. Clin Chim Acta. 2008;388:135-8.

26. Yokozawa T, Sekiya M, Cho EJ, Kurokawa M, Shiraki K. Effect of Wen-Pi-Tang extract on lung damage by influenza virus infection. Phytomedicine. 2004;11:625-32.

27. Guisti G, Bernard S. Methods of Enzymatic Analysis. Academic Pres Newyork. 1974; 1092-9.

28. Worthington-Enzyme Manual. Enzymes, Enzyme Reagents, related Biochemicals. Worthington Biochemical Corporation in Freehold, New Jersey, U.S.A. 1972; pp. 216.

29. The reports of Communicable Diseases Department, Ankara, Turkey: Ministry of Health 2007.

30. Midilli K, Gargili A, Ergonul O, Sengöz G, Ozturk R, Bakar M. Imported Crimean-Congo hemorrhagic fever cases in Istanbul. BMC Infect Dis. 2007;7:54.

31. Chan B, Wara D, Bastian J, Hershfield MS, Bohnsack J, Azen CG, et al. Long-term efficacy of enzyme replacement therapy for adenosine deaminase (ADA)-deficient severe combined immunodeficiency (SCID). Clin Immunol. 2005;117:133-43.

32. Nyhan WL. Disorders of purine and pyrimidine metabolism. Mol Genet Metab. 2005; 86:25-33.

33. Moriwaki Y, Yamamoto T, Higashino K. Enzymes involved in purine metabolism - a review of histochemical localization and functional implications. Histol Histopathol. 1999;14:1321-40. 
34. Conde MB, Marinho SR, Pereira Mde F, Lapa e Silva JR, Saad MH, Sales CL, et al. The usefulness of serum adenosine deaminase 2 (ADA2) activity in adults for the diagnosis of pulmonary tuberculosis. Respir Med. 2002;96:607-10.

35. Vorbach C, Harrison R, Capecchi MR. Xanthine oxidoreductase is central to the evolution and function of the innate immune system. Trends Immunol. 2003;24:512-7.

36. Cevik MA, Erbay A, Bodur H, Gülderen E, Baştuğ A, Kubar A, et al. Clinical and laboratory features of Crimean-Congo hemorrhagic fever: predictors of fatality. Int J Infect Dis. 2008;12:374-9.

37. Burt FJ, Paweska JT, Ashkettle B, Swanepoel R. Genetic relationship in southern African Crimean-Congo haemorrhagic fever virus isolates: evidence for occurrence of reassortment. Epidemiol Infect. 2009; $137: 1302-8$

38. Deyde VM, Khristova ML, Rollin PE, Ksiazek TG, Nichol ST. CrimeanCongo hemorrhagic fever virus genomics and global diversity. J Virol 2006; 80:8834-42.
39. Alataş F, Uslu S, Moral H, Alataş O, Metintaş M, Erginel S, et al. Serum adenosine deaminase activity in pulmonary tuberculosis. Tuberk Toraks. 2003;51:277-81.

40. Fang J, Nakamura H, Iyer AK. Tumor-targeted induction of oxystress for cancer therapy. J Drug Target. 2007;15:475-86.

41. Stirpe F, Ravaioli M, Battelli MG, Musiani S, Grazi GL. Xanthine oxidoreductase activity in human liver disease. Am J Gastroenterol. 2002;97:2079-85.

42. Papa A, Bino S, Velo E, Harxhi A, Kota M, Antoniadis A. Cytokine levels in Crimean-Congo hemorrhagic fever. J Clin Virol. 2006;36:272-6.

43. Ergönül O, Tuncbilek S, Baykam N, Çelikbaş A, Dokuzoguz B. Evaluation of serum levels of interleukin (IL)-6, IL-10, and tumor necrosis factor-alpha in patients with Crimean-Congo hemorrhagic fever. J Infect Dis. 2006;193:941-4. 